\title{
MATERNAL CARE PRACTICES, IMMUNIZATION, AND THEIR ASSOCIATIONS WITH GASTROENTERITIS AMONG INFANTS IN NORTHTAPANULI, NORTH SUMATERA
}

\author{
Yuslina Fanny NB Siahaan, Evawany Y Aritonang, Taufik Ashar \\ Graduate Program in Public Health, Faculty of Public Health, \\ Universitas Sumatera Utara
}

\begin{abstract}
Background:Gastroenteritis is the inflammation in gastric and small intestinal mucosal membrane indicated by the symptoms as diarrhea, nausea, vomit and light fever accompanied by appetite loss and uneasy feeling in the stomach. Gastroenteritis in infants is caused by several factors, including bacterial or viral infections, and food intolerance. This study aimed to investigate the associations of maternal care practices and immunization with the incidence of gastroenteritis among infants in NorthTapanuli, North Sumatera.

Subjects and Method: This was a case control study conducted in North Tapanuli, North Sumatera. A sample of 94 infants aged 7 to 12 months was selected for this study, consisting of 47 infants with gastroenteritis and 47 infants without gastroenteritis. The dependent variable was gastroenteritis. The independent variables werematernal care practice(dietary and health) as well as immunization status. The data were collected by questionnaire and analyzed by a multiple logistic regression model.

Results:The incidence of gastroenteritis in infants was associated with incorrect maternal dietary care practice $(\mathrm{OR}=8.20 ; 95 \% \mathrm{CI}=2.58$ to $26.31 ; \mathrm{p}<0.001)$, improper maternal health care practice $(\mathrm{OR}=5.02 ; 95 \% \mathrm{CI}=1.54$ to $16.32 ; \mathrm{p}=$ 0.007), and absence of immunization $(\mathrm{OR}=4.60 ; 95 \% \mathrm{CI}=3.42$ to $15.96 ; \mathrm{p}=$ 0.016).

Conclusion: Maternal dietary and health care practices and immunization are associated with the incidence of gastroenteritis among infants.
\end{abstract}

Keywords: gastroenteritis, dietary, health, maternal care practice, immunization, infant.

\section{Correspondence:}

Yuslina Fanny NB Siahaan. Graduate Program in Public Health, Faculty of Public Health, Universitas Sumatera Utara, Medan, North Sumatera.

Email: fannybintangshn@gmail.com. Mobile: 081265565433. 